\title{
ペルプレン緩衝工に㗢く波力について
}

三田 重雄*・庄司 邦昭 *
大和俊一朗 $* *$ 橋本 一明 *

\section{Wave Force Acting on the Pelprene Protective Device}

\author{
Shigeo MITA, Kuniaki SHOJI, Shunichirou YAMATO \\ and Kazuaki HASHIMOTO
}

\begin{abstract}
Recently large bridges have been constructed in navigable waters congested by ships, so that ship collision with bridge piers is on the increase. To decrease the accidents various kinds of protective system are planned. The pelprene protective devices is developed for one of these protection systems. The shape of the cross section is honeycomb which is made from thermoplastic polyester elastomers named Pelprene. Usually honeycomb structure have been used for the bumper of the cars and have seldom been used for the offshore structure.

In this paper the authors made a study of the wave forces acting on the protective devices by model experiments to decide how to install them around the bridge pier.

The following results are obtained.

The wave forces acting on the pelprene protective device model are smaller than that of the identically shaped box model.

The horizontal forces:Fx have a maximum value at the region; $\lambda / L=3 \sim 5$.

The vertical forces:Fz are smaller than horizontal forces in all the region of $\lambda / \mathrm{L}$ and have a flat distribution.

In comparison with a model made from steel, Fx of the pelprene model is larger than that of steel model and $\mathrm{Fz}$ is smaller than that of steel model.
\end{abstract}

\section{1.はじめに}

近年、船舶の輻輳する海域に瀬戸大橋に代表されるような巨大な橋梁が建設され、船舶が橋脚に衝突す る事故が発生している。このような事故を防ぐための緩衝施設として、橋脚の周囲に鋼製のブロックやゴ 么製の浮き袋等を取り付け、直接的な衝突を避けて双方の被害を少なくするための緩衝工が実用化されて いる。こうした中で、材料にゴムとプラスチックの両方の特性を有するTPE (熱可塑性ポリエステルエラ ストマー) の一種であるペルプレンを用いたペルプレン虐衝工（以下 "PEL緩衝工”を表す）が開発され、 実用化に向けて色々な実験が行われている(1)。この緩衝工は、ハニカム状に成型した部材で作られており、 衝突による衝撃は座屈変形で緩和・吸収される。

ハニカム構造は身近なものでは自動車のバンパーにも衝撃吸収材として使われているが、海洋構造物に 適用した研究例は見受けられない。本研究は、海洋構造物としてのハニカム状のPEL緩衝工の一研究であ る。今回、橋脚への取り付け方法を検討するため、東京商船大学・船舶運航性能実験水槽で波力実験を行 った。この結果、PEL緩衝工に衝く波力の特性がほぼ把握できたので報告する。水槽実験の実施時期は平

* 正 会 員 東京商船大学（干135 東京都江東区越中島 $2-1-6)$

**学生会員 東京商船大学大学院（干135 東京都江東区越中島 $2-1-6$ ) 
成 6 年 10 月（基礎実験） $と 7$ 年 2 月 (応用実験)， 6 月（基礎実験 の追加および確認) である。

\section{2. 実験の方法}

\section{1 供試模型}

波力実験に用いたPEL緩衝工模型の成型部材を、図 1(a)，(b)に 示す。(a)は実物大の $1.0 \mathrm{~m}$ 四方のもので、ハニカム状の凹凸の数が $7 \times 7$ である。また、(b)は凹凸の数が(a) とは異なる $5 \times 5$ で、縮 尺1/5に作られた $0.2 \mathrm{~m}$ 四方のものである。

緩衝工の基本特性を調べる基礎実験に用いた模型は、(a)の部材 を前後方向の張り出し長さ $(\mathrm{L}) \times$ 高さ $(\mathrm{D}) \times$ 幅 $(\mathrm{B})$ を $1.0 \times 1.0 \times 3.0$ (m) に組み立てた実寸・単体模型（重量 $330 \mathrm{~kg}$ ） と、(b)の部材を $0.2 \times 0.2 \times 0.6(\mathrm{~m})$ に組み立てた縮尺・単体模型（重量 $2.2 \mathrm{~kg}$ ）、こ の縮尺・単体模型をL方向またはD方向に 2 個連結した $2 \mathrm{~L} 、 2 \mathrm{D}$ 模 型、および縮尺・単体模型大のアクリル板製箱形模型である。こ れらの模型の概略を図 2 に示す。

想定した実機の特性を調べる応用実験に用いた模型は、(b)の部 材で実機寸法の $1 / 5$ の大きさ $(\mathrm{L} \times \mathrm{D} \times \mathrm{B}=0.8 \times 0.6 \times 0.72(\mathrm{~m})$ 、重 量 $42 \mathrm{~kg}$ ) に組み立てたPEL緩衝工実機模型（以下 “PEL実機模型” と表す）と、比較のために既に実用化されている多室構造型の鋼 製緩衝工をモデル化した縮尺 $1 / 5(\mathrm{~L} \times \mathrm{D} \times \mathrm{B}=0.9 \times 0.6 \times 0.72(\mathrm{~m})$ 、 重量 $39 \mathrm{~kg}$ ）の鋼製実機模型とである。鋼製実機模型を図 3 に示す が、重量を減らすため波の当たらない上部を省略し、水面下の高 さも約 $3 / 4$ にて波の影響の大きい水面付近をモデル化した。

\section{2 実験・計測装置}

実験を行った船舶運航性能実験水槽は、 有効長さ $50 \times$ 幅 $10 \times$ 水深 $2(\mathrm{~m})$ で (実験時水 深 $1.9 \mathrm{~m}) 、$ 、ラップ型の造波装置と曳航電車 が設置されている。緩衝工模型は波力計測 用のロードセルを介し、曳航電車に搭載し た上下動装置に図4のように取り付けて水 槽のほぼ中央に設置した。また、緩衝工模 型の背面に、橋脚を想定した取り外し可能 な高さ $1 \mathrm{~m}$ 壁を設置した。写真 1 に、PEL 実機模型での実験状況を示す。

使用したロードセルは 3 分力ロードセル （日章電機、LMC-3504-5、LMC-3504-50、 アンプ：ユニパルス、AM10)で、実寸模型 ではX軸 $\varepsilon \mathrm{Y}$ 軸方向の 2 分力 $Z Z$ 軸周りのモ ーメントを、実寸模型以外ではロードセル の取付方向を変え、X軸とZ軸方向の 2 分力

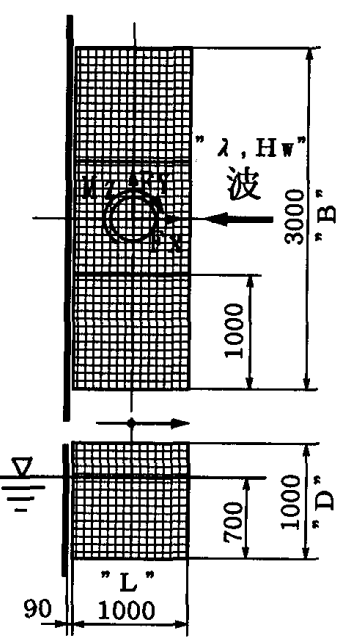

実寸・単体模型
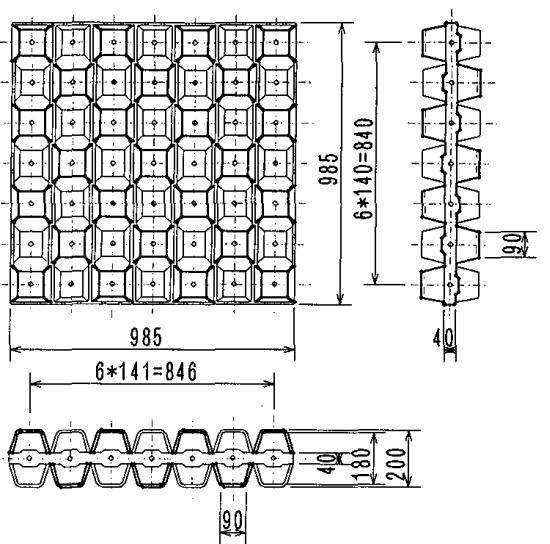

(a)実寸模型

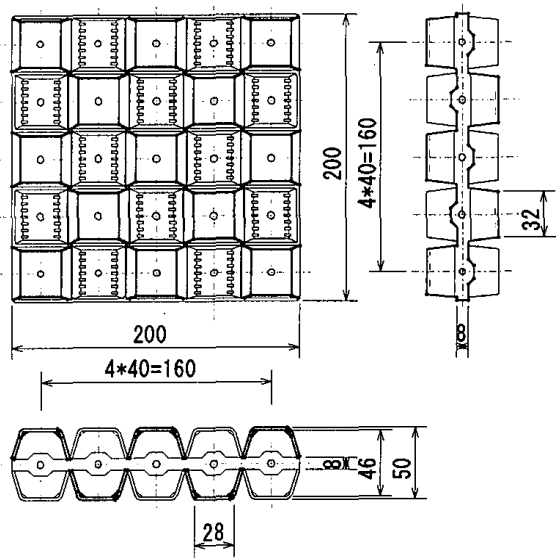

(b)縮尺模型

図 1 PEL緩衝工の成型部材

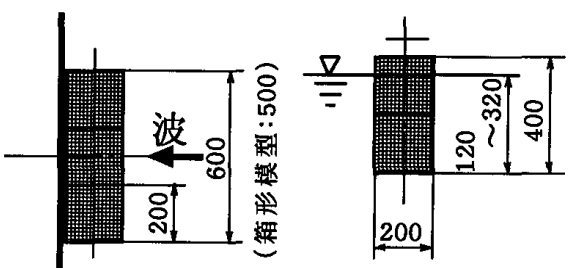

$2 \mathrm{D}$ 模型

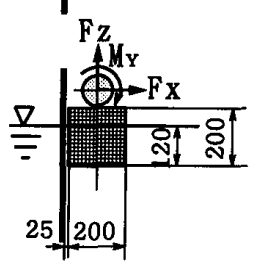

縮尺·単体模型

（箱形模型）

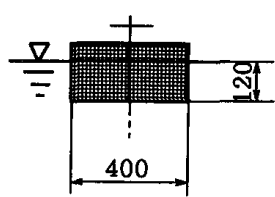

$2 \mathrm{~L}$ 模型

図 2 基礎実験用PEL緩衝工模型

とY軸周りのモーメント（計測点が壁面から ほぼL/2離れているので、ここで計測された值は橋脚取り付け時のモーメントとは異なる)を計測した。ま た、造波装置で起こした波 (入射波) は、模型前方に設置した容量式波高計（計測技研、CH-403）で計測 した。これらのデータは、曳航電車上でペンレコーダ（グラフテック、WR-3701）仁記録し、解析に供し た。 


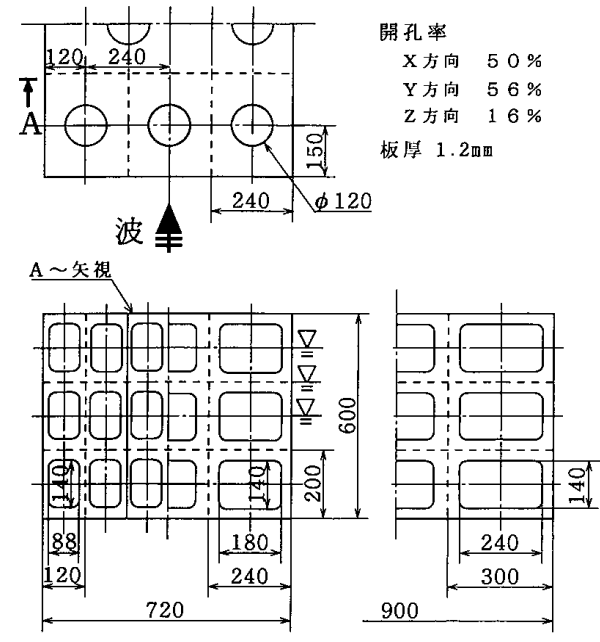

図 3 鋼製実機模型の形状

\section{3 実験条件}

今回行った波力実験の実験状態を表 1 に示す。 基礎実験においてはPEL緩衝工の特性を多方面 から把握する目的で、緩衝工模型を単体で置い た状態 (“壁無し”と表す) と、橋脚を想定した 壁を設けた状態（“壁有り”と表す）の実験とを 行った。また、応用実験においてはすべて壁有 りとし、鋼製緩衝工と比較した。使用した波は、 波長0.7 - 11m、波高12～90mmの規則波で、主に 幅方向の正面から当てた。なお、実機模型と2 D模型については、喫水を変化させた。

計測した入射波と波力は、ペンレコーダの記 録波形から peak to peakの值を読みとり、次式 により無次元化して実験結果を表した。

張り出し方向の力: $F x$

$$
C x=F x /(\rho \cdot g \cdot d \cdot B \cdot H w)
$$

幅方向の力 : $F y$

$$
C y=F y /(\rho \cdot g \cdot L \cdot B \cdot H w)
$$

上下方向の力 : $F z$

$$
C z=F z /(\rho \cdot g \cdot L \cdot B \cdot H w)
$$

$Y$ 軸回りのモーメント：My $C M y=M y /\left(\rho \cdot g \cdot L^{2} \cdot B \cdot H w\right)$

$Z$ 軸回りのモーメント : $M z C M z=M z /\left(\rho \cdot g \cdot L^{2} \cdot B \cdot H w\right)$

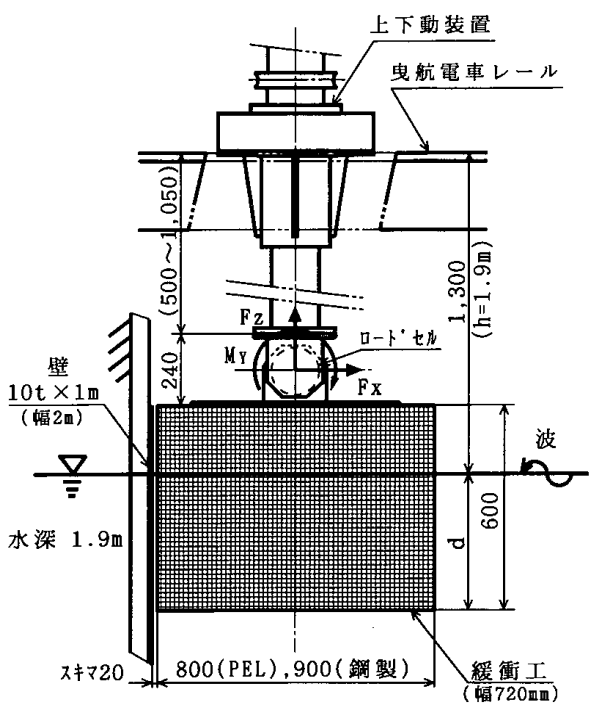

困 4 緩衝工模型の設置

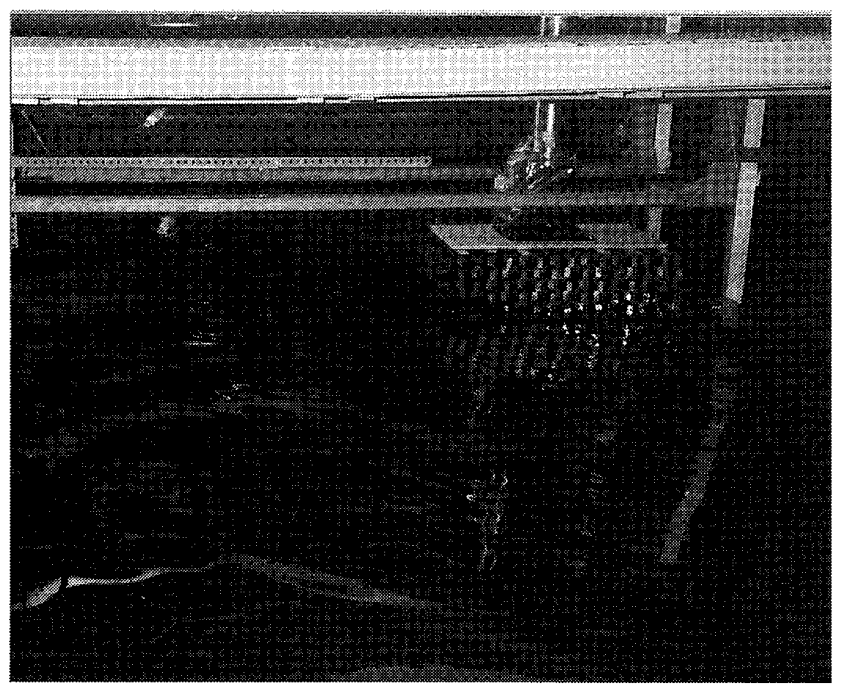

\begin{tabular}{|c|c|c|c|c|c|c|c|}
\hline 実験名 & 模型名 & 材質 & 形状，繀 & 尺等 & 組合せ名称 & 寸法 $(\mathrm{L} \times \mathrm{D} \times \mathrm{B}(\mathrm{m}))$ & 壁の有無 \\
\hline \multirow{5}{*}{ 基礎実験 } & 実寸模型 & PEL製 & 2Q型 & $S=1 / 1$ & 単体模型 & $1.0 \times 1.0 \times 3.0$ & 有り、無し \\
\hline & \multirow{3}{*}{ 縮尺模型 } & \multirow{3}{*}{\multicolumn{3}{|c|}{ PEL製 4AR型 $S=1 / 5$}} & 単体模型 & $0.2 \times 0$ & b、無 \\
\hline & & & & & $2 \mathrm{~L}$ 模型 & $0.4 \times 0.2 \times 0.6$ & 無 \\
\hline & & & & & $2 \mathrm{D}$ 模型 & $0.2 \times 0.4 \times 0.6$ & $\begin{array}{l}\text { 無 } \\
\end{array}$ \\
\hline & 箱形模型 & アク & ル板製 & & 単体模型 & $0.2 \times 0.2 \times 0.5$ & 有 \\
\hline \multirow[t]{2}{*}{ 応用実験 } & \multirow[t]{2}{*}{ 実機模型 } & PEL製 & 4AR型 & $S=1 / 5$ & PEL実機模开 & $0.8 \times 0.6 \times 0.72$ & 有 \\
\hline & & 鋼製 & 多室型 & $S=1 / 5$ & 龬製実機模 & $0.9 \times 0.6 \times 0.72$ & 有 \\
\hline
\end{tabular}

写真 1 PEL実機模型の実験状況

表 1 実験状態一覽表 


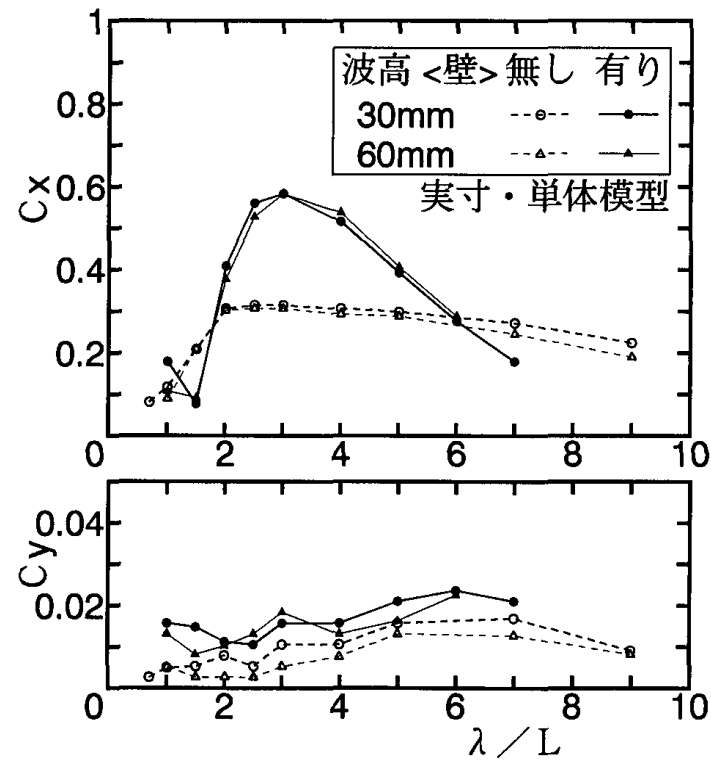

図 5 実寸・単体模型に働く波力

ここに、 $\rho$ : 流体の密度、 $g$ : 重力加速度、 $L:$ 緩衝工の張 り出し長さ $(\mathrm{m}) 、 B:$ 緩衝工の幅 $(\mathrm{m}) 、 d:$ 緩衝工の契水 $(\mathrm{m}) 、 H w$ : 波高 $(\mathrm{m})$ である。また、波長 $\lambda(\mathrm{m})$ は、張 り出し長さ $L て ゙$ 割った値 $\lambda / L$ 用いて表した。

\section{3. 実験の結果および考察}

\section{1 基礎実験の結果}

基礎実験の結果を、図 5 10に示寸。

図 5 は、実寸・単体模型の壁無しと壁有りの状態にお ける、波高30、60 mm時の波力を示す。四によると、ぼの 力の成分も、壁有りは壁無しょりも大きな値になってい る。また、壁有りの場合、Cxは $\lambda / L=3$ のところで最大 値をとっていて、壁無しの 2 倍になっている。Cxは波高 の大きさによる変化がなく、波力は波高に比例して大き くなっている。この実験状態は橋脚に取り付けられた緩 衝工の正面から波を受ける場合に相当しており、Cyは $C x$ よりも十分小さいことを示している。図 6 蛙、縮尺・単 体模型の、壁無しと壁有りの状態における波高 $12 、 30 \mathrm{~mm}$ 時の波力を示寸。Cxは実寸・単体模型の結果とほぼ同様 で、 $\lambda / L=4$ 付近で最大となり、 $\lambda / L=15$ 付近からは壁 無しと壁有りの差がなくなっている。Czも全体的に壁有

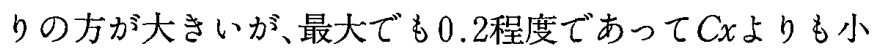
さい。CMyは、Cx 变化の傾向がよく一致している。こ れは、Myを模型上面の中心で計測しているので、主に $F x$ が作用しているものと思われる。したがって、緩衝工を

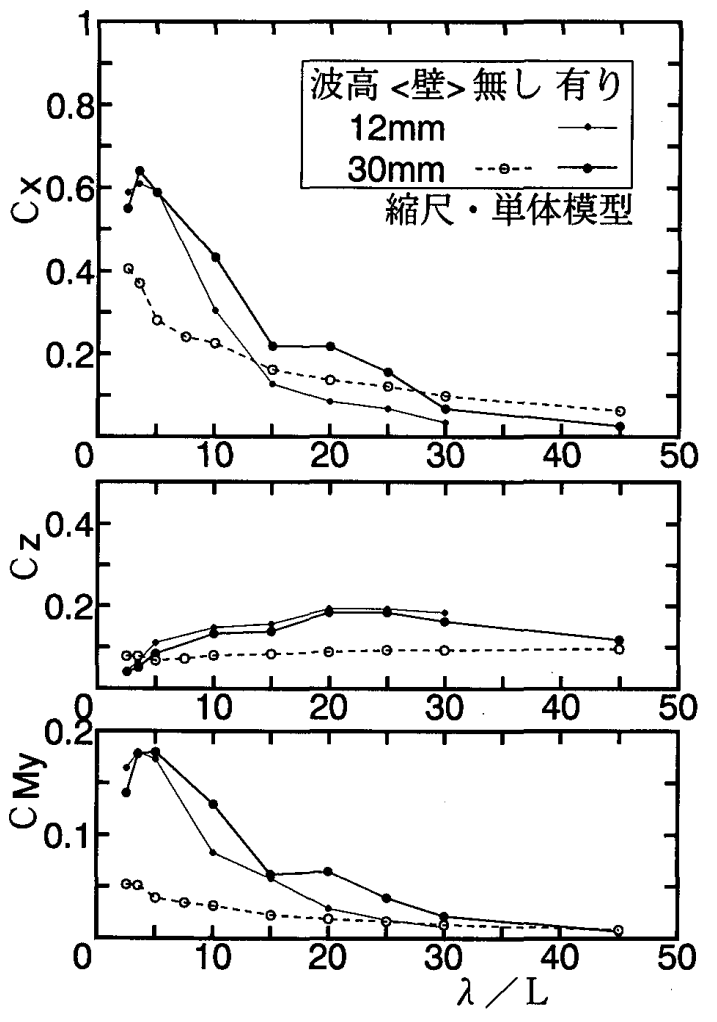

図 6 縮尺・単体模型に衝く波力

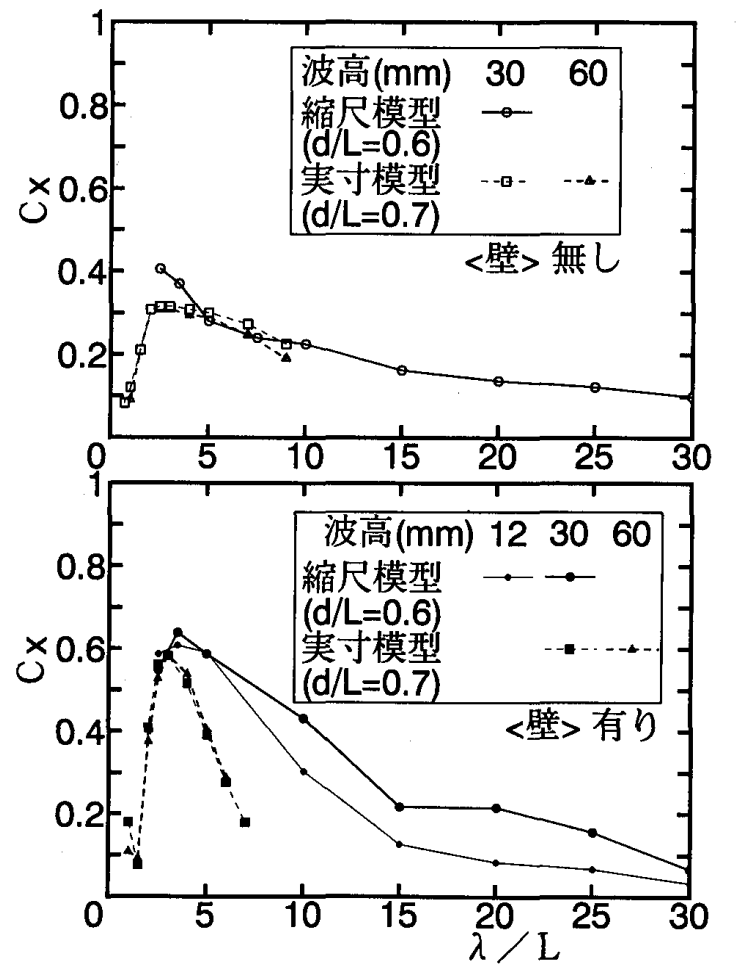

目 7 実寸と縮尺模型の波力の比較

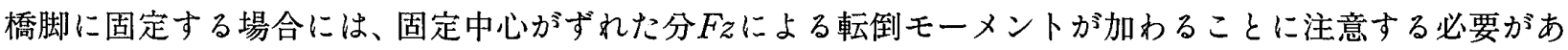
る。また、壁有りでは $C x 、 C M y$ は、波高が大きいほぼ幾分大きくなっている。図 7 は、Cxを壁無しと壁有 りについて、実寸模型と縮尺模型を比較して寸法影響を表したものである。前述のとおり全体的な傾向は 

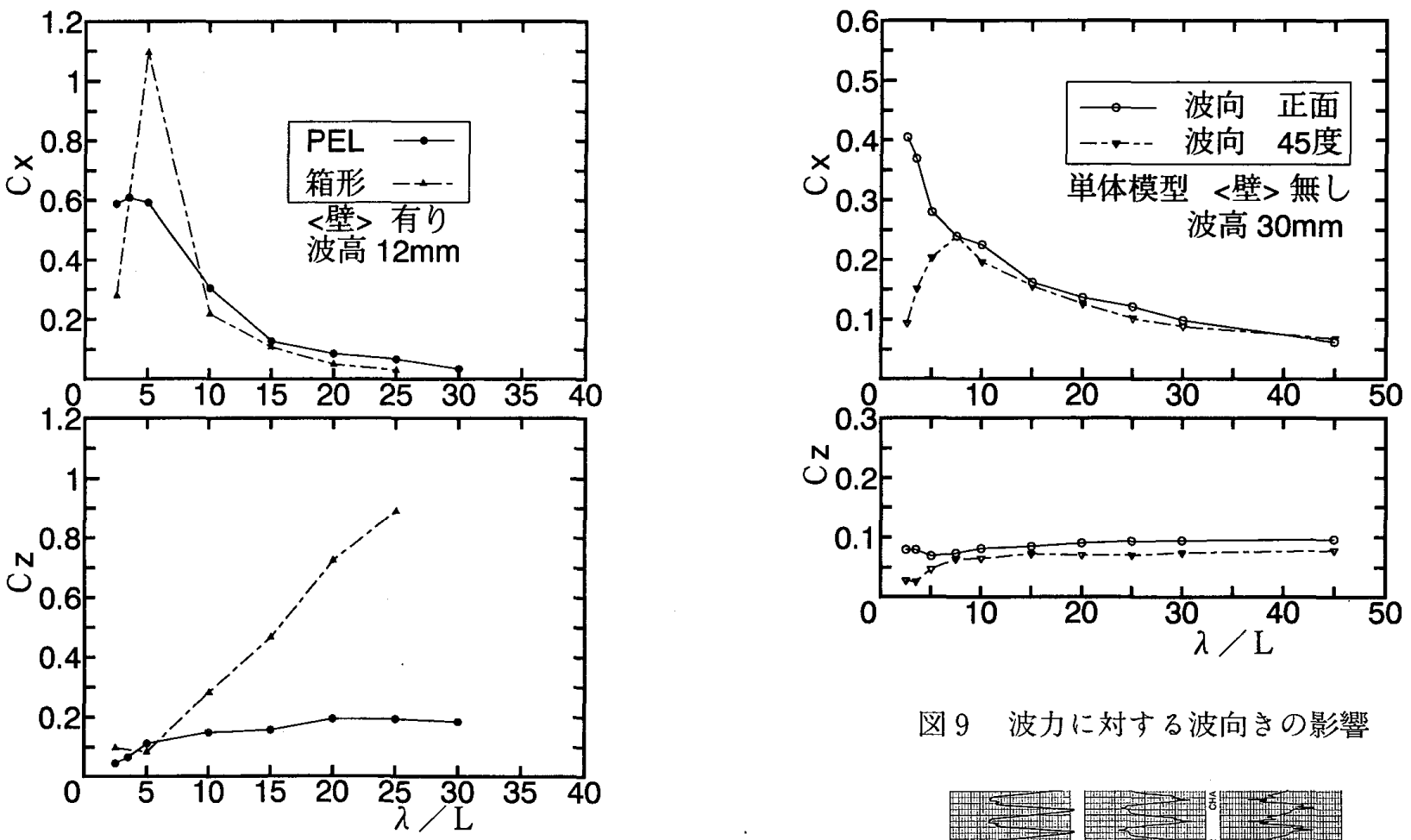

図 9 波力に対する波向きの影響

図 8 箱形模型との波力の比輘

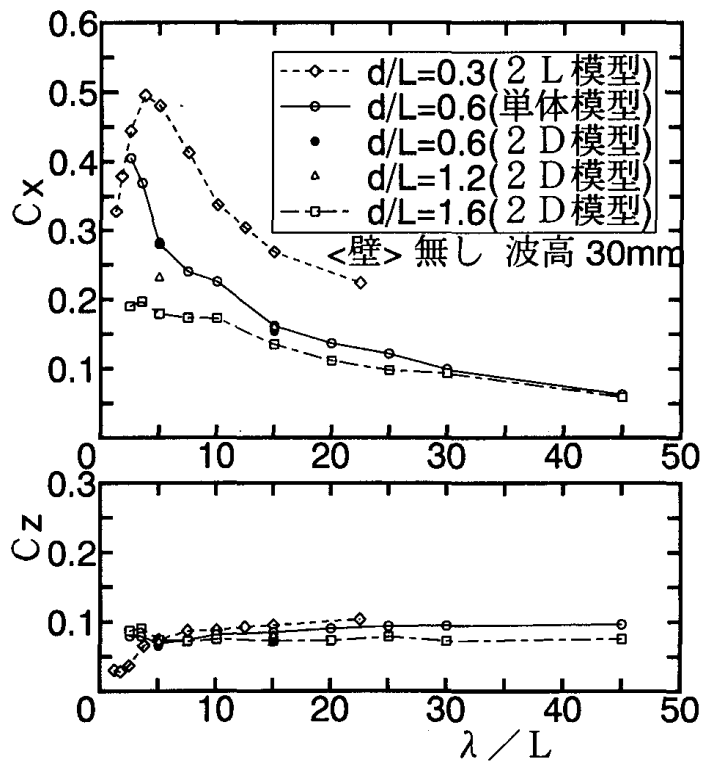

図10 波力に対する喫水の影響
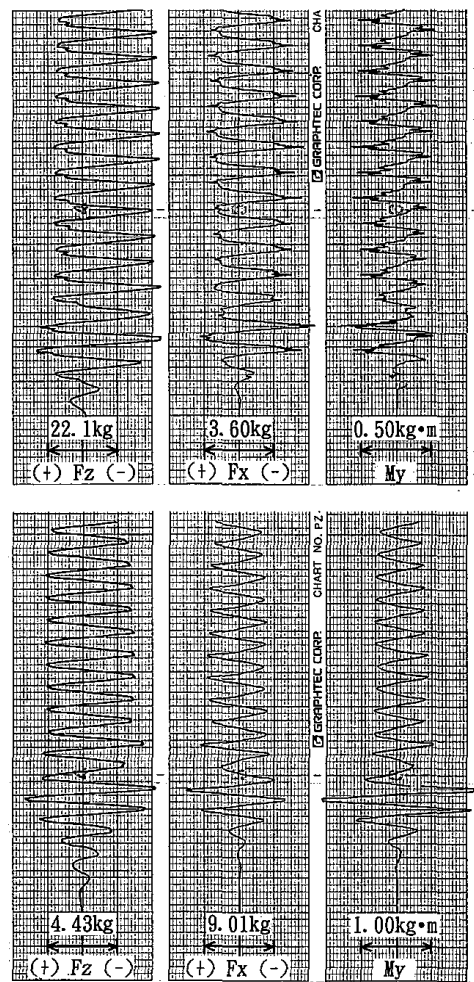

図11＼cjkstart実機模型の記録波形の例

(a)PEL緩衝工 $\quad \lambda=9 \mathrm{~m} \quad H w=73 \mathrm{~mm}$ (b)鋼製緩衝工 $\quad \lambda=11 \mathrm{~m} \quad H w=90 \mathrm{~mm}$

一致しているが、いずれも縮尺模型の方が多少大きくなっている。この理由として、図 1 に示したように 凹凸の構成が異なること、 $d / L$ 值が少し違うこと等が考えられる。

図 8 は、壁有りの状態で、箱形模型と縮尺・単体模型に㗢く波力を比較したものである。図において、 $C x$ 変化の傾向は一致しているが、最大值が箱形模型では 1 に近くなっている。また $C z$ も、箱形は波長の 增加とともに増加し、1に近づいている。この図からハニカム状の部材からなるPEL緩衝工は、同規模の 平板で構成された箱形模型よりも、受ける波力が小さいことがわかる。 


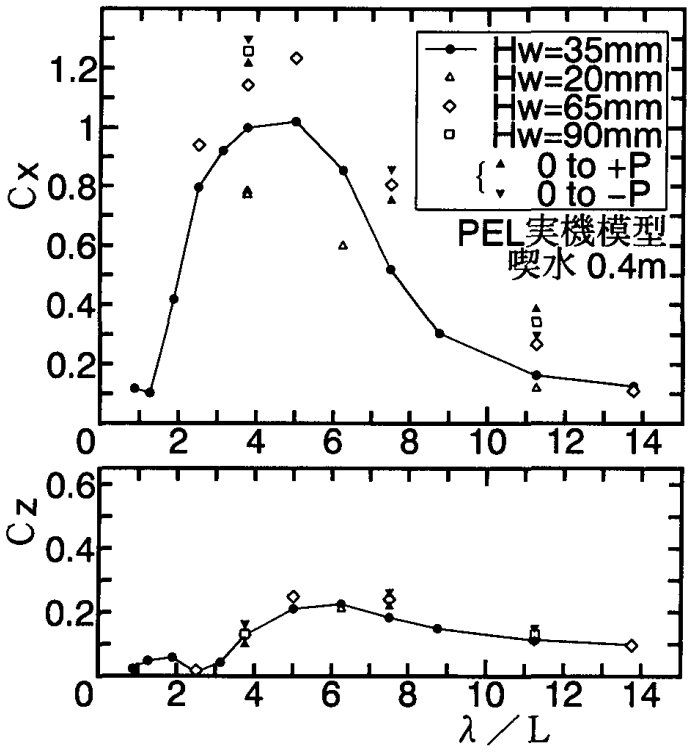

図12 PEL緩衝工模型に㗢く波力

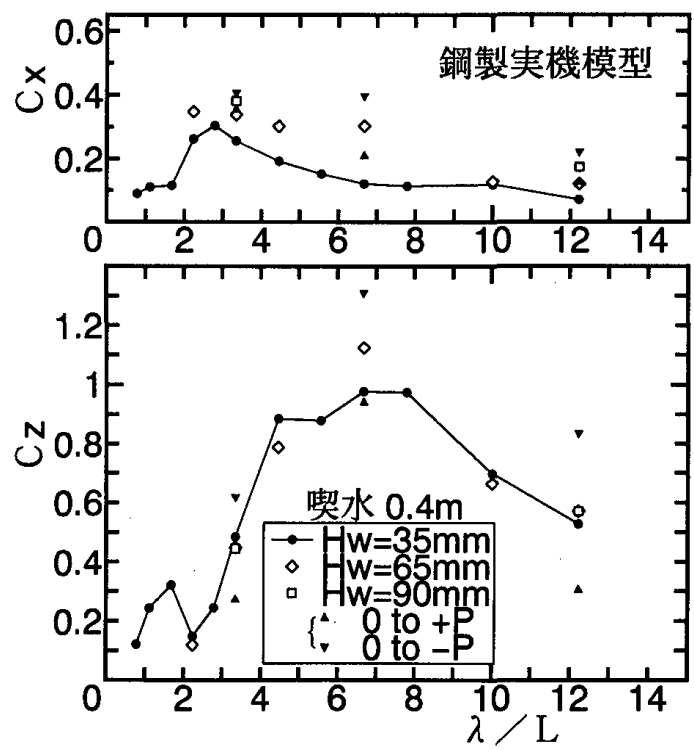

図13鋼製緩衝工模型に働く波力

図 9 は、壁無しの状態で緩衝工に対する波向が変化した 場合について示したものである。45度の方向から波を受け た場合、正面から波を受けた場合に対し、張り出し方向の 力の係数 $C x$ と上下方向の力の係数 $C z$ は幾分、減少すること がわかる。図10は、壁無しの状態で、縮尺・単体模型と 2 L模型、および喫水 $\mathrm{d}$ を変化させた $2 \mathrm{D}$ 模型の波力を、 $d / L$ をパラメータとして示したものである。Cxは入/L=4 付近 でいずれも最大值をとる。この值は $d / L$ がすいほぼ大きく なる傾向を示して扣り、水面付近で波力の大きいことがわ かる。CZについてはd/Lによる変化は小さい。

3.2 応用実験の結果

応用実験での記録波形の例を図11に、結果を図12１4に 亦す。

図12は、PEL実機模型の契水0.4m、波高20～90mmにおけ

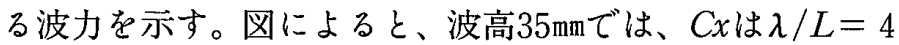
付近で最大值 1 をとるが、波高の大きさによって係数 $C x の$ 違いもあらわれている。これは図 6 に示した壁有りの傾向 と一致している。一方 $C z$ は、 $\lambda / L=6$ 付近で最大值 0.2 を っている。図13は、鋼製緩衝工模型の契水 $0.4 \mathrm{~m}$ 、波高

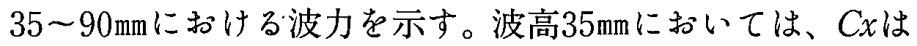

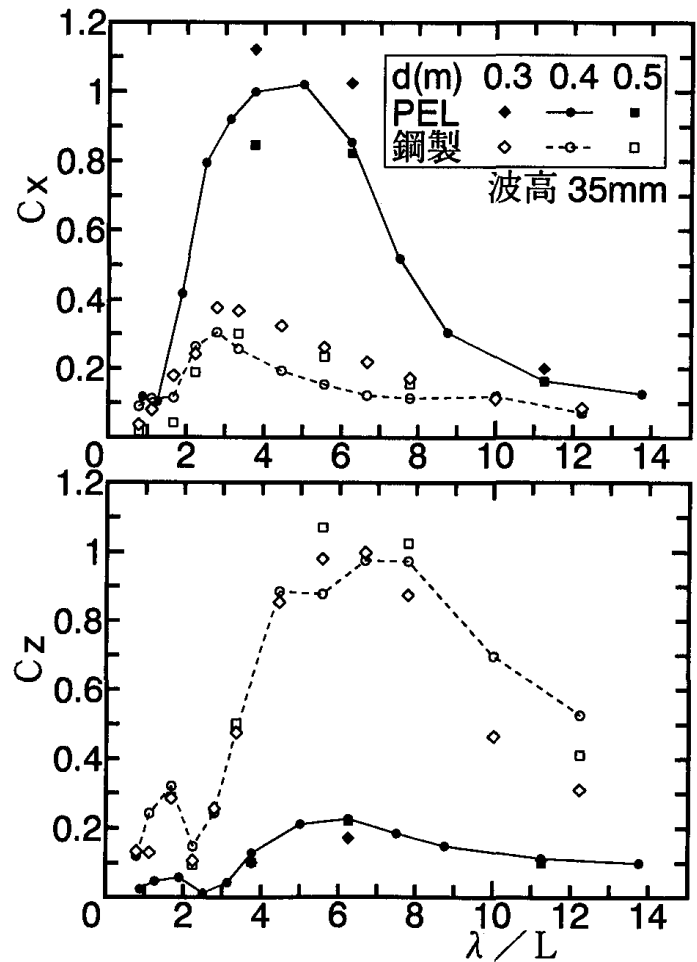

困14 実機模型による波力の比較 $\lambda / \mathrm{L}=3$ 付近で最大值 0.3 をと、PEL緩衝工よりも小さい。 また、Czは $\lambda / L=6$ 付近で最大值 1 となり、Cxとは逆にPEL緩衝工よりも大きく、緩やかな減少を示し、 $\lambda / L=12$ においては0.6位の值をとっている。多室構造になっている鋼製緩衝工では、図 119 波力の記録例 (ローパスフィルタ $\left.f_{C}=10 \mathrm{~Hz}\right)$ にも見られるように、Fx、Fzとも衝撃波状の鋭いとがりを示し、十側と一 側で大きさが数10\%異なるものもあった。PEL緩衝工ではこのような衝撃波形は見られなかった。この様 子も、波高の大きい数点について 0 to \pm peakの値を読みとり、

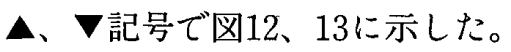

図14は、PEL緩衝工模型と鋼製緩衝工模型の波高35mmにおける喫水と波力の関係を示したものである。 $C x の$ 值は、PEL緩衝工では $\lambda / L=4 \sim 7$ 付近で喫水 $d か ゙$ 小さいほど大きくなっており、基礎実験で調べた のと同様 $d / L$ にって変化している。一方、鋼製緩衝工は、実験の範囲内において喫水が变わると係数 $C x 、$ 
$C z$ の両方の值が変化することを示している。これは、図 3 に示したように、鋼製緩衝工模型は高さ方向が

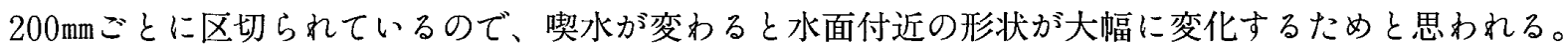

\section{4. まとめ}

ハニカム状の部材でできたPEL緩衝工の水槽実験を実施し、いくつかの波力特性がつかめた。主なもの は、

・PEL緩衝工は、同規模の平板で構成された箱形よりも、受ける波力が小さい。

$\cdot P E L$ 緩衝工の張り出し方向の力 $F x$ は $\lambda / L$ に対して山形の変化を示し、 $\lambda / L=3 \sim 5$ 付近で最大となる。 上下方向の力 $F z$ の最大值は、これよりも小さく、緩やかな変化を示す。

・喫水变化に対寸る波力の增加割合は喫水が小さいほど大きく、水面付近の影響が大きい。

・鋼製䌅衝工と比較すると、FxはPEL緩衝工の方が大きく、逆にFzはPEL緩衝工の方が小さい。

等であり、このような特性を考慮した取り付け方を行う必要がある。

波力に対する実機性能を評価するに当たっては、まだ十分なデータが揃ったとは言えない。大波高の実 験や、複数連なって設置されたときの相互干涉の問題等が考えられる。模型の縮尺比をもっと上げて小さ くすることにより、実験も容易になり、実験項目の多様化も図れるので、今後の課題とする。

最後に、本研究の実施にあたり多大なご指導を頂いている東京商船大学商船学部武井幸雄講師、並びに 多大なご協力を頂いている東洋紡績株に感謝の意を表します。

\section{参 考 文 献}

（1）庄司・有田：船船の衝突に対するペルプレン緩衝工の特性に関する研究，テクノ・オーシャン’94. 国 際シンポジウム PROCEEDINGS VOLUMEII, pp.577-581, 1994.10.

\section{質 疑 応 答}

大津皓平 (東京商船大学)：x方向とz方向で波力が、PELと鋼製とは異なった傾向がでていますが、ビちら の波力が小さい方が緩衝工としては良いのでしょうか。

三田重雄：取付部の強度から見ると、z方向の波力が小さい方が良いといえます。すなわち、緩衝工の水面 より上の部分は橋脚に容易に固定できますので、固定部に働く波力のモーメントは、喫水に比べて張り 出し長さの方が大きく、レバーが長い分Z方向の波力影響が大きくなるからです。 